\title{
6. Turning Subjects into Objects and Objects into Subjects: Collecting Human Remains on the 1948 Arnhem Land Expedition
}

\author{
Martin Thomas
}

\section{The Archaeologist Removes the Bones}

He's taking the bones now, taking the bones. He reaches into the hollow of a crevice; the rear of his trousers, protruding towards the camera, is stained with channels of sweat. Turning to face us, he unwraps a mandible from a blackened shred of rag. Bespectacled, and with lips pursed beneath a trim moustache, his officer's deportment is upset by a slash of blue headband that gives him a piratical craziness. He adds the jaw to a wooden crate already full of arm and leg bones, butted up against a skull. The guts of this narrative - if 'guts' is quite the word when we are dealing with bodies so fleshless - hinge on this and other kindred events.

At the time of writing, it is more than sixty-five years since the bones were extracted from their not-quite-final resting place. Much is forgotten in so long a period of time, and yet the story of the stolen bones from Arnhem Land is far from buried (although it did end with an interment). Captured on celluloid, projected onto the surface that is the present, the theft is possessed of a luminous immortality. As raw spectacle, the bone taking is irksome and yet compelling; a trait accentuated by the conversion of the footage to digital format, bringing as it does a brave new world of accessibility and convenience. ${ }^{1}$ I can stop, start and magnify the image while I write; pull it apart like some anatomist of the screen. It was always intended that the act of seizure would transcend the fleetingness of the event itself. The archaeologist's diary makes it clear, as might be supposed, that the presence of the cameraman was anything but accidental. ${ }^{2}$ Between them, the archaeologist and the cameraman made of the

\footnotetext{
1 Howell Walker (cine-photographer), Aboriginal Australia (lecture film), 1950, National Geographic Society, Washington DC. For further detail of the film see Joshua Harris, ‘Hidden for Sixty Years: The motion pictures of the American-Australian Scientific Expedition to Arnhem Land', in Exploring the Legacy of the 1948 Arnhem Land Expedition, eds Martin Thomas and Margo Neale (Canberra: ANU E Press, 2011).

2 'Diaries 1948' Frank Maryl Setzler Papers 1927-1960, Box 14, National Anthropological Archives, Suitland MD, 28 October 1948 (henceforth Frank Maryl Setzler Papers 1927-1960).
} 
theft a pedagogical performance, perhaps in an effort to give it scientific import. We see the archaeologist lifting and handling the skull, pointing out distinctive features, before slotting the jaw in place and presenting to the camera its largely toothless grin. The final seconds of the sequence show a glimpse of scenery from the hilltop where the event occurred: a body of water, a yellowed strip of land, a few scant dwellings. The archaeologist and another white man (of whom more will be said later) cross the frame as they clamber downhill. Manhandling the crate - lidded now, and destined for America - they disappear from the picture.

The pillaging of a mortuary site and the decision to film it are sufficient to unsettle many a viewer. For Aboriginal people with whom I have watched the footage, the close physical handling - the intimate contact of the living flesh of the intruder with the remains of the interred - is particularly unnatural and disturbing. In processing my own response, I have come to realise that there are technical aspects to the footage that accentuate the violence and uncanniness of the actions portrayed. The content of the film is unashamedly atavistic - it stinks of the nineteenth century - yet it is shot in colour. Colour film usually has a soundtrack, but this is silent. His mute presence and the absence of an ambient acoustic give a ghostliness to the archaeologist and the scene he inhabits. While his actions involve dislocation, a wealth of evidence concerning his activities means that the events depicted can be precisely located in space and time. The film was shot on 28 October 1948 near the top of Injalak, a hill just outside the perimeter of what was then known as Oenpelli Mission in the Northern Territory of Australia. ${ }^{3}$ Oenpelli, which lies to the east of Kakadu National Park, is now a township, more often known by its Kunwinjku name, Gunbalanya. The archaeologist, who was employed as Head Curator of Anthropology at the Smithsonian Institution in Washington DC, was visiting this western region of the great Arnhem Land Aboriginal Reserve as a member of the AmericanAustralian Scientific Expedition to Arnhem Land (otherwise known as the Arnhem Land Expedition).

The man who documented the seizure of bones from Gunbalanya was the photographer Howell Walker, official representative of the National Geographic Society (NGS) on the Arnhem Land Expedition (see Figure 1). As a staff writer/ photographer who spent much time in Australia, Walker was responsible for many of the stories on the Pacific that appeared in National Geographic Magazine in the mid-twentieth century. ${ }^{4}$ On the Arnhem Land Expedition he had with him a large supply of colour film stock, still scarce in Australia in 1948. His $16 \mathrm{~mm}$ camera, a lightweight machine powered by a windup mechanism,

3 ibid., 28 October 1948 .

4 See Mark Collins Jenkins, 'A Robinson Crusoe in Arnhem Land: Howell Walker, National Geographic and the Arnhem Land Expedition of 1948', in Exploring the Legacy of the 1948 Arnhem Land Expedition, eds Martin Thomas and Margo Neale (Canberra: ANU E Press, 2011), 73-85. 
shot vision only. By that time it was common for documentary filmmakers to edit their silent footage into a coherent narrative and add a studio-generated soundtrack that might include music, commentary and 'canned' sound effects. But no soundtrack was ever created for the Arnhem Land film shot by Walker. Instead, as was common practice at the NGS - ever devout to the cult of the roving adventurer - the footage was edited into a silent presentation to which a lecturer (in this case the archaeologist) spoke, slideshow style. ${ }^{6}$ The longevity of this type of film presentation was due in part to the caution with which the Society responded to the rising medium of television. Not until 1958 did the NGS allow one of its productions to grace the small screen. ${ }^{7}$ In the immediate post-war era, the Society's documentary films, usually conceived as spinoffs to National Geographic articles, were shown exclusively to live audiences and thereby treated as inseparable from the travelling lecturer: a flesh-and-blood talisman of the events and geography depicted therein.

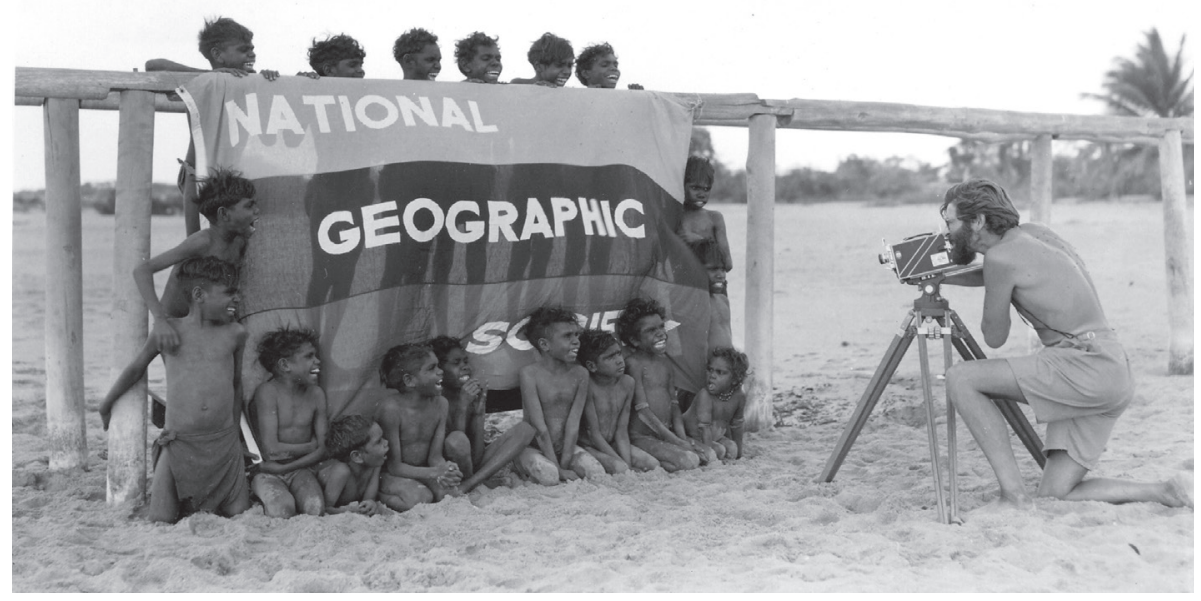

Figure 1: Howell Walker from the National Geographic Society photographing at Umbakumba, 1948. Photograph by Charles P. Mountford.

Source: By permission of the State Library of South Australia. PRG 487/1/2/209/1.

While the theft and its documentation by the filmmaker constitute the originary performance that I will investigate and contextualise in this chapter, it cannot be separated from a sequence of subsequent performances that should be recognised as short- and long-term reverberations of the primary event. Having performed

5 For more on audio for film in this period, see Jones, this volume.

6 Walker, Aboriginal Australia.

7 Robert M. Poole, Explorer's House: National Geographic and the world it made (New York: Penguin, 2004), 226. 
the theft for the camera, the archaeologist, when he had returned home to the US, took the lecture film on the road and performed to his earlier performance of taking the bones, morphing from museum curator into showman. The words he used when he performed to the Arnhem Land film are recoverable, for a typescript of his narration, carefully composed and synchronised, still survives in a ring binder among his papers. As the footage of him handling the skull was projected, he would declare:

These specimens are most important to the science of physical anthropology. Note the pathological condition above the right orbit, the large mastoid process of the male, and these bony ridges for the attachment of the neck muscles. This skull will not only be well preserved in the Smithsonian but will contribute much to the study of these primitive aborigines. Even though we could not obtain all the skeletal material I had located, that which I did bring back constitutes one of the largest collection [sic] of Australian material in this country. ${ }^{8}$

The pronouncement that the haul of human remains would be subject to scientific study was erroneous. There is no evidence that even a single scientific paper analysing the Arnhem Land bones was ever published. Although much of what he said in the film lecture is deeply suspect, the archaeologist's prediction that the bones would be 'well preserved' was shown to be correct when, sixtytwo years later, in a latterday reverberation of the bone theft, I was on the outskirts of Washington with cinema-photographer Adis Hondo, where we were doing some filmmaking of our own. The bones collected by the archaeologist had by this time reached the end of their long tenure in the US. After ten years of delay and disagreement, the Department of Anthropology in the Smithsonian Institution's National Museum of Natural History had consented to a request from the Australian government that the bones be returned to their places of origin. Now they were packed in cartons, ready to travel to their home Country. These flimsy boxes - coffins of cardboard - were stacked on a flat-base trolley and wheeled outside into bright sunlight, each draped in an Aboriginal flag. The three colours of the flag-red for land, black for people, yellow for sunhad never seemed more vibrant or poignant. A handful of smouldering gum leaves were waved around the boxes by Joe Neparrnga Gumbula, an elder from Elcho Island and one of three men who had come from different parts of Arnhem Land to receive the remains of their ancestors and accompany them home. Clap sticks beat as Gumbula sang. With a whiff of Australian bushfire in the Washington air, Howell Walker's footage of the theft, long internalised, played in my mind. And I thought of the archaeologist, deceased for many a year, whose archives - which betray so much about the taking of the bones-lay in storage in a building a hundred metres away.

8 'Film Lecture', Box 20, Frank Maryl Setzler Papers 1927-1960. 
The theft of the bones in 1948, their removal to Washington, their recovery and repatriation in the early twenty-first century, and the eventual interment of some of them in ancestral territory marks an orbit - wide in breadth and profound in impact - that I wish not only to describe and analyse, but to subject to a type of archaeological investigation; one that is attuned to a postcolonial, rather than a colonial, paradigm. The presence of human remains in museum collections has been the subject of organised contestation by Indigenous groups from many parts of the world at least since the 1970s. One of the few points of agreement in the large and ever-growing literature on this subject is the diversity of institutional responses to the repatriation phenomenon. Some organisations have embraced it and come to celebrate the improved relations with Indigenous communities that have developed as a consequence. Others have resisted it, while a number, especially in the US, have had it forced upon them through legislation.

Arguments between supporters and opponents of repatriation invariably involve a clash of values and knowledge systems. Consider, as an example, some remarks by the British archaeologist Don Brothwell, lamenting the trend towards repatriation in the journal Antiquity. In a 2004 article he argued that rationalism must prevail and scientists be allowed to pursue their analysis of these remains, which is of universal benefit: 'We are surely now living in a world, when all understand geological and astronomical time, and there is no sense in denying it in order to prop up old cultural mythologies. ${ }^{9}$ In just the sort of argument that Brothwell was hoping to dispel, Joe Gumbula explained his thinking about the ceremony that ushered the Arnhem Land bones out of the Smithsonian Institution. Gumbula explained that the choice of funeral songs that he would perform was determined by the needs of the people in the cardboard boxes who required the guidance of familiar languages to steer them homeward.

These people will be listening to us too. They know. It's not us doing the show, or doing this business just today, for the eyes of the public or the eyes of the living people here now. They are listening to us. ${ }^{10}$

Gumbula's view on the relationship between the living and the dead which, though subject to regional variation, is broadly shared by those Aboriginal people from various parts of Arnhem Land with whom I have discussed this issue. A person's spirit remains indelibly associated with the bones of the deceased. Living people have responsibilities towards the spirit, as much as they do to each other.

Brothwell and Gumbula have very different beliefs about the world, although both of them attach value to the dead. It's just that they do so in such divergent

9 Don Brothwell, 'Bring out Your Dead: People, pots and politics', Antiquity 78:300 (2004): 415.

10 Joe Neparrnga Gumbula in interview with the author, 30 June 2010. 
ways. For Brothwell, it is a morally defensible position that human remains are collectable. They can be subject to handling and analysis by persons who have no cultural or familial association with them because the expiration of their life force has rendered them biological remnants. No longer human subjects, they can be treated as objects and stored in an institution where researchers might use them to advance their knowledge of the greater human story. For Gumbula, in contradistinction, death has not altered their subject status. As was the case when they were living and breathing, they can still expect to connect with, and reside within, their ancestral Country. Gumbula's obligations to the deceased are in no way affected by scientific theories about the origins of humanity.

In investigating this case study of a bone theft, and in plumbing the life stories and intellectual genealogies of its chief perpetrator, it is this subject/object dichotomy that I want to expose and analyse. How and in what situations do we objectify? What is the relationship between objectification and power? Those questions - which go to the heart of both colonial and postcolonial relationsare the fulcrum of my inquiry here. In exploring them, the transformation of human subjects into museum objects can be seen as part of a much larger history, being part of an array of social and cultural practices that are as much to do with relations between living persons as they are between the living and the dead.

\section{Trans-National Journeys}

What to say of the Arnhem Land Expedition, the vehicle for the theft of the Arnhem Land remains, which ran for much of 1948? Firstly, to locate it temporally, it was conceived in the last year of the Second World War - a moment of liminality, for the end of hostilities was by then discernible, although the geopolitics of the post-war age had yet to be hammered out. For Australia, the strategic and historical connections with the United Kingdom had been battered by the wartime experience, while the future relationship with the US seemed uncertain. ${ }^{11}$ This was the moment when Australia's Department of Information, of which the America-friendly Arthur Calwell was minister, sent the Adelaide photographer-cum-ethnologist Charles P. Mountford (1890-1976) on a mission to raise awareness of the island-continent by giving lectures and exhibiting films throughout the US. Mountford's documentaries, depicting Aboriginal life in central Australia, were shot during extensive journeys by camel around Uluru (known to him as Ayers Rock) and Kata Tjuta (the Olgas), at that time seldom seen by anyone but their traditional owners (see Figure 2).

11 See Kim Beazley, 'Nation Building or Cold War: Political settings for the Arnhem Land Expedition', in Exploring the Legacy of the 1948 Arnhem Land Expedition, eds Martin Thomas and Margo Neale (Canberra: ANU E Press, 2011), 55-71. 


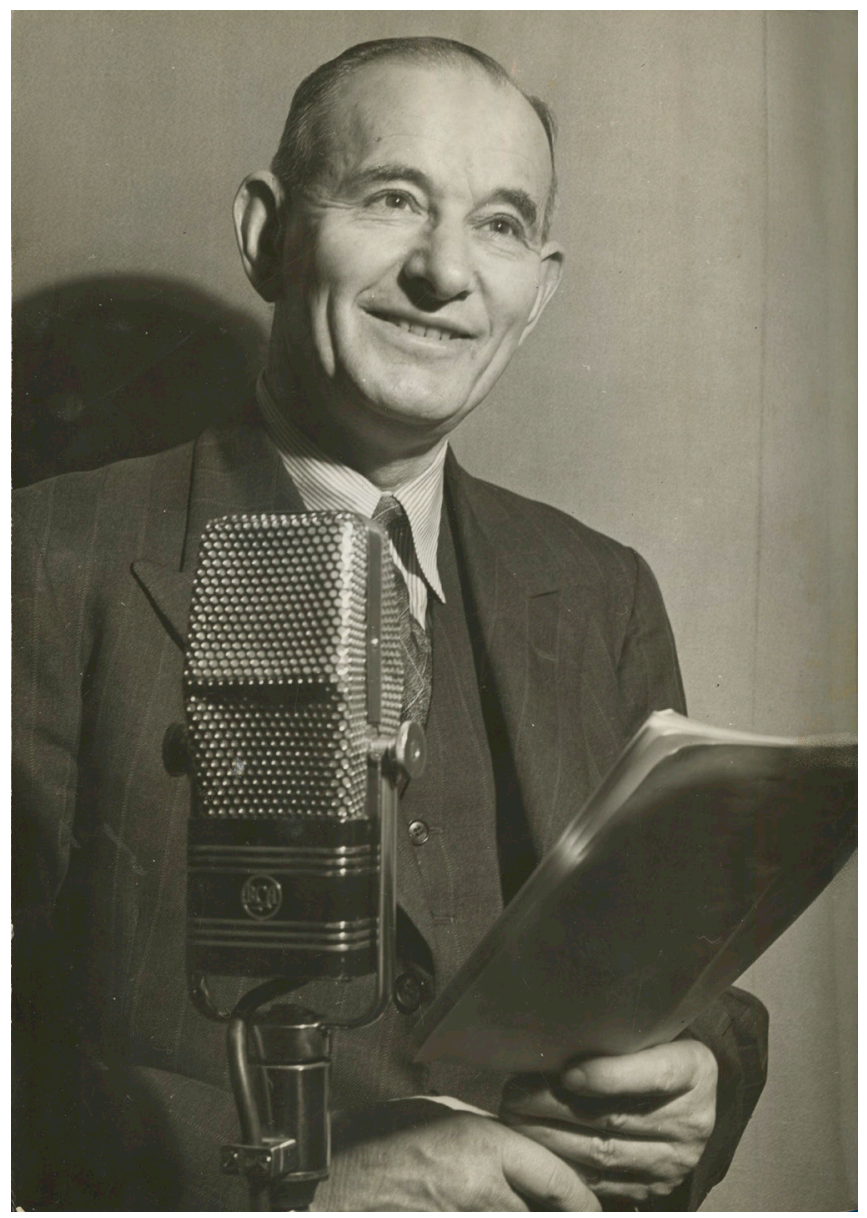

Figure 2: Charles P. Mountford during his lecture tour of the United States, 1945.

Source: By permission of the State Library of South Australia. PRG 1218/16/2.

The pedigree of the 1948 bone theft has many branches. All of them, including Mountford's dissemination of Australian film in the US, involved the dislocation of cultural materials and their circulation in contexts where they were utterly foreign. Mountford's film tour, a key example of this pattern of dislocation and circulation, was a finely tuned exercise in the cultivation of the exotic. ${ }^{12}$ His time abroad reveals conflicts and contradictions that would resurface in the expedition he led three years later.

12 See Haskins, this volume. 
Although his reputation has waned in the years since his death in 1976, for much of the mid-twentieth century, Mountford was a highly visible figure in Australian cultural life. In his home state he enjoyed special prominence as a local boy made good; the press would write of him as 'among the greatest' of South Australians. Mountford's improbable rise from working-class obscurity as a telephone mechanic to globetrotting authority on Australian Aborigines was enabled in the first instance by his proficiency as a photographer. As a camera club enthusiast in Adelaide, he was encouraged by officials at the South Australian Museum to document rock art. This kindled an interest that led him to participate in museum-backed expeditions to Aboriginal settlements where he took photos and studied mythology, which he documented by distributing paper and crayons and encouraging local artists to draw their legends. ${ }^{13}$ In the field of Aboriginal studies, Mountford is best remembered as a writer and collector, but it is worth remembering that he began his career as a visual communicator. Interest in the visual arts lay at the heart of his preoccupation with Aboriginal culture. This explains his passion as a collector and promoter of Aboriginal art, which he did much to popularise on the international stage. ${ }^{14}$ Deeply humanist in its vision, Mountford's oeuvre is distinguished by intimate portraiture of Aboriginal people in their homeland settings, as is evident in his photographs of Mawalan Marika and his son Wandjuk, who worked extensively with the 1948 expedition when it was stationed at Yirrkala in north-east Arnhem Land (see Figures 3 and 4). Mountford always argued that the dignity, creativity and morality of the people whom he studied must be recognised. In his visits to Aboriginal communities, he photographed everyone from babies to octogenarians, producing images that were attractive and highly efficacious in portraying the individuality and subjectivity of a people who had been endlessly typecast, degraded and objectified. The universalism of Mountford's approach to his Aboriginal subjects resonates strongly with other humanist deployments of photography in the mid-twentieth century, most notably the famed The Family of Man exhibition, curated by Edward Steichen for the Museum of Modern Art (MOMA) in New York in 1955 which, when it went on tour, became an international sensation.

13 Philip Jones, 'Inside Mountford's Tent: Paint, politics and paperwork', in Exploring the Legacy of the 1948 Arnhem Land Expedition, eds Martin Thomas and Margo Neale (Canberra: ANU E Press, 2011), 33-54.

14 See Philip Jones, 'Perceptions of Aboriginal Art: A history', in Dreamings: The art of Aboriginal Australia, ed. Peter Sutton (Ringwood: Viking, 1988), 143-79. 


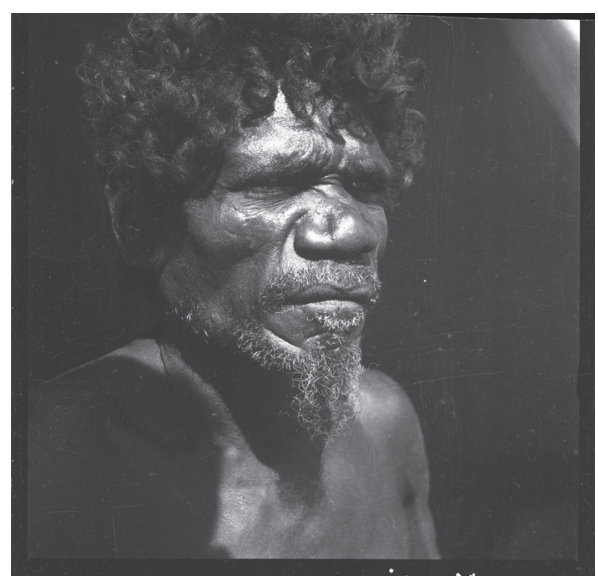

Figure 3: Portrait of Mawalan Marika, 1948. Photograph by Charles P. Mountford.

Source: By permission of the State Library of South Australia. PRG 1218/17/26.

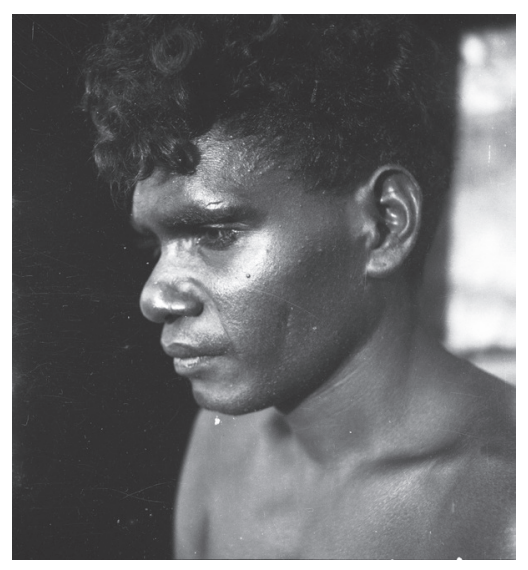

Figure 4: Portrait of Wandjuk Marika, 1948. Photograph by Charles P. Mountford.

Source: By permission of the State Library of South Australia. PRG 1218/17/26.

Like The Family of Man, the humanist doctrine espoused by Mountford was in various ways conflicted. His personal cachet as a humanitarian was due to his preparedness to work among people whom he regularly described as the most primitive in the human family. The extent and limits of his empathy are suggested in his public pronouncements, as we see in an interview, published in an Indiana newspaper in 1945, in which he claimed to have made eight or 
ten expeditions to central Australia where he studied 'the earth's most primitive people', the Pitjantjatjara. With some astonishment, the journalist reported that these people were so simple that they had

less than five tools, and not more than ten personal possessions. They wear no clothing, not even a g-string and build no houses. They wander about their country, living off the land, killing kangaroos ... Interesting people, no doubt, but what has our civilization to learn from theirs?

Mr Mountford thinks it has plenty.

"They are a fundamental society," he says, "and if we can get a complete study of them, how they live, what tools they use, what beliefs and philosophies they have, how they can live without warfare, how they can balance their laws so well, - if we can learn that, perhaps we can apply some of what we learn to our own problems.

"Here is a human society that works simply and well, while our complex society is working badly ... I am consecrating the rest of my life to the task of helping to make these people understood by our people. I believe if I do that, I shall have made a small contribution to human betterment." 15

Some intimation of the power of Mountford's presentations can be found in responses from those who saw them. Mountford always kept his fan mail, preserving it in a detailed diary-cum-scrapbook that he maintained throughout his American tour. One writer was John P. Harrington, an official at the Smithsonian Institution's Bureau of Ethnology, whose encounter with Mountford's films of primordial Australia came close to a religious experience.

The introductory background talk was enlightening and the colored motion pictures showed a country beautiful in coloration in addition to containing the most primitive humans in the entire world ... We have nothing in America equal to the primitiveness of these Australian people. I thank God for the privilege of having been able to witness what is really worth while. ${ }^{16}$

Ever confident of his altruistic motives, Mountford enjoyed a remarkable ascendancy by riding the surge of interest in 'traditional' or 'primitive' arts that was taking hold in metropolitan centres, especially in the US. Throughout its

15 Maurice Frink, 'Home Town Slants: Man From Australia', Daily Truth (Elkhart, Indiana), undated press cutting in C. P. Mountford, 'A Journey to America 1944-5', Vol. 9, PRG 1218/16/9, Mountford-Sheard Collection, State Library of South Australia (SLSA), Adelaide, 766.

16 Harrington to Mountford, 10 March 1945, Mountford 'A Journey to America 1944-5,' Vol. 9, PRG 1218/16/9, Mountford-Sheard Collection, SLSA, 1080. 
history, modernism has exhibited an interest in, and orchestrated an impressive array of dalliances with cultures and societies categorised as 'primitive'. While the roots of this fascination extend back to the nineteenth century and beyond, the Second World War brought a new and rather different attitude towards socalled traditional societies - a development we might associate with reactions to Nazism and the use it made of scientific racism. Other factors were at work here, most notably the move towards decolonisation, inflected as it was by the prominence of Africa, Asia and the Pacific as theatres of war where all sorts of collaboration between servicemen and native populations had occurred. Certainly, new attitudes towards formerly colonised people were gaining acceptance, and the very notion of racial difference was being disputed. In 1950, UNESCO issued its landmark declaration that '[f]or all practical social purposes "race" is not so much a biological phenomenon as a social myth". ${ }^{17}$

While Mountford himself was not a collector of human anatomy, and considered himself a great friend to 'the Aborigine', he was nonetheless at home with the pre-war certitudes of a racially categorised humanity. At a film screening in Chicago, he complained about audience members who 'start up with describing the aborigines as low, mentally and physically, whereas my talk shows them to be the opposite' ${ }^{18}$ In Chicago's Field Museum of Natural History he looked with fascination through the Hall of the Races of Mankind, with its ninetyplus sculptures by Malvina Hoffman representing the human species in its multitudinous forms. Here too, Mountford would criticise the detail, but not the underlying principle. ${ }^{19}$ The sculptures of Aborigines were not done from life, he complained; the depiction of Aboriginal women was 'definitely libellous'. He noted that if Hoffman had 'seen the Abo as I have, her statue of him would be very different'. ${ }^{20}$ Yet Mountford was sufficiently intrigued by this woman sculptor, a former student of Rodin who had attained so prominent a position in the art and museum world, that he sought to meet her. She invited him to her studio where they had a productive conversation. ${ }^{21}$

Mountford's mission of providing a corrective within a racialised, developmental paradigm provided him with extraordinary opportunities to develop his career in the US. Between lecture engagements, he spent time knocking on doors and

\footnotetext{
17 UNESCO, 'The Race Question', 18 July 1950, accessed 1 July 2014, http://unesdoc.unesco.org/ images/0012/001282/128291eo.pdf.

18 Mountford 'A Journey to America 1944-5,' Vol. 4, PRG 1218/16/4, Mountford-Sheard Collection, SLSA, 1473.

19 The historian Michelle Brattain has described Hoffman's anthropological sculptures as typical of a pre-

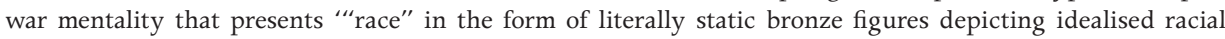
"types"'. Michelle Brattain, 'Race, Racism, and Antiracism: UNESCO and the politics of presenting science to the postwar public', American Historical Review 112:5 (2007): 1407.

20 Mountford 'A Journey to America 1944-5,' Vol. 4, PRG 1218/16/4, Mountford-Sheard Collection, SLSA, 1461.

21 ibid., 1570.
} 
canvassing support for various projects. He consistently gained access to key officials in leading institutions. In New York he was called upon to advise René d'Harnoncourt, a curator at (and future director of) MOMA, on the Australian Aboriginal content for Arts of the South Seas (1946), a book and blockbuster exhibition of Oceanic art. ${ }^{22}$ Mountford at that stage had never been to Arnhem Land, but he had written about its culture of bark paintings, as represented in the collections of the South Australian Museum. ${ }^{23} \mathrm{D}^{\prime}$ Harnoncourt invited him to help negotiate the loan of these paintings and other objects for the MOMA exhibition. ${ }^{24}$ The MOMA show presented a carefully arranged smorgasbord of Pacific cultures in which the Aboriginal material had special status. Mountford noted in his diary: 'The opening court of the show is to be Australian, the most primitive ... It should be an excellent show and bring Australia well to the fore. $^{25}$

Mountford won a great many friends and admirers when touring the US. Among them were executives at the NGS who raised the prospect of awarding him a research grant for an Australian project. This was the point at which the idea of an expedition to Arnhem Land began to coalesce. When NGS funds were promised, the Smithsonian Institution became interested to the extent that it offered to provide scientific personnel, four of whom were eventually assigned to the expedition. Minister Calwell, delighted at this coming together of flagship US institutions on Australian soil, arranged for the Commonwealth Government to become an official partner. The American-Australian Scientific Expedition to Arnhem Land, as it became known, was an all-round anthropological, natural history, photographic and filmmaking adventure - a seven-month odyssey intended as an overt display of bilateral friendliness. Needless to say, the inhabitants of Arnhem Land were never consulted about the visitation of this scientific and propagandist extravaganza. ${ }^{26}$

The 1948 expedition was spawned by Mountford's films of central Australia, and it provided the occasion for another-and much larger - set of cultural objects and records to be thrown into circulation. With museum curators on its payroll, all eager to expand the collections of their own institutions, the expedition was a wholesale exercise in the collection of data and objects. Its

22 Mountford's role in the exhibition is documented in his US diaries, cited above, and in Ralph Linton, Paul S. Wingert and Rene D'Harnoncourt, Arts of the South Seas (New York: Museum of Modern Art, 1946), 6, 190-5.

23 Charles P. Mountford, 'Aboriginal Decorative Art from Arnhem Land, Northern Territory of Australia', Transactions of the Royal Society of South Australia 63:2 (1939), 365-71.

24 D'Harnoncourt to Mountford, 19 April 1945, Mountford, 'A Journey to America 1944-5', Vol. 4, PRG 1218/16/4, Mountford-Sheard Collection, SLSA.

25 ibid., 10 April 1945, 1503-5.

26 This summation of the expedition is drawn largely from Martin Thomas, 'A Short History of the 1948 Arnhem Land Expedition', Aboriginal History 34 (2010); and Martin Thomas and Margo Neale, eds, Exploring the Legacy of the 1948 Arnhem Land Expedition (Canberra: ANU E Press, 2011). See also Sally K. May, Collecting Cultures: Myth, politics, and collaboration in the 1948 Arnhem Land Expedition (Lanham: AltaMira Press, 2010). 
gatherings included scientific and anthropological reports, popular publications, ethnological collections (including a great many examples of Aboriginal art), sound recordings and numerous examples of still and moving photography. The removal of human remains fell within this broader project of collection.

\section{The Archaeologist and his Context}

In my opening description of the bone theft and its documentation on film, I deliberately left the archaeologist nameless. Tempting as it is to continue in this vein, and thereby detach him from his social fabric and identifiers, as he did the men, women and children who became 'specimens' in his collection, I will not do so. To replicate his logic is to submit to its limitations (and these are considerable). Much more can be said of his actions and their consequences if his individuality is recognised.

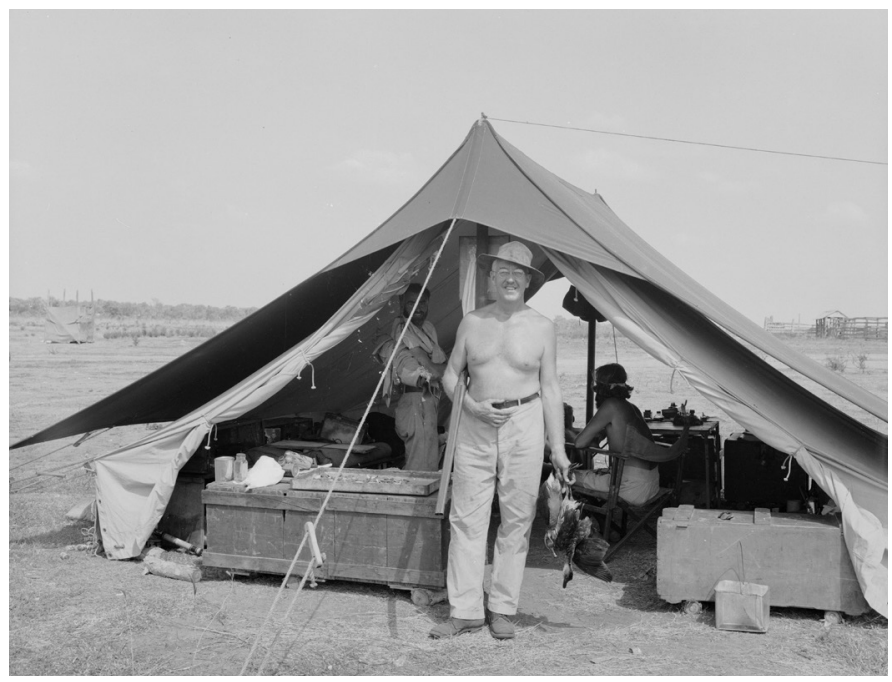

Figure 5: Frank Setzler at Gunbalanya (Oenpelli Mission) during the American Australian Scientific Expedition to Arnhem Land, 1948. Photographer unknown.

Source: By permission of the National Anthropological Archives, Smithsonian Institution. Photo Lot 36 Oenpelli_128.

The name of the bone taker was Frank Maryl Setzler (1902-1975) (see Figure 5). By 1948, when he went to Australia, he was something of an old hand at the Smithsonian, having joined the institution's US National Museum (now the National Museum of Natural History) in 1930. As the most senior of the four Smithsonian scientists who went to Arnhem Land in 1948, he served as 
deputy leader of the expedition. Setzler did his undergraduate study at the State University of Ohio and then moved to Chicago where he received an allround training in social and physical anthropology, graduating as a Bachelor of Philosophy $(\mathrm{PhB})$ in 1928. For the next two years he remained at Chicago as a graduate student. While often, perhaps mostly, known as 'Dr Setzler' (he was invariably referred to as such in the Australian press), he had no doctoral qualification. ${ }^{27}$ The $\mathrm{PhB}$ was sufficient to win him the job at the US National Museum, which seems to have perfectly matched his interests and ambitions. Setzler's sympathies were with the museum side of anthropological study, where the analysis of material culture took precedence over the social and kinship study that preoccupied so many academic anthropologists in this period, and where opportunities for excavation and collection building abounded. His previous work experience had included curatorship at the state museum in Ohio, where he grew up. ${ }^{28}$ He worked as the state archaeologist in Indiana before winning the Smithsonian appointment. By 1930, the Smithsonian was already a gargantuan museum and research organisation, centred in Washington DC and named after its benefactor, the English chemist James Smithson (c. 1765-1829). Although a single 'institution', administered by a Secretary and governed by a Board of Regents, it is in reality an unwieldy conglomeration that includes national museums, zoological gardens, art galleries, herbaria, research stations and libraries. In number of staff and size of collections, it is the leviathan of the museum world.

Setzler's obituary in the Washington Post included a photograph of him surrounded by bark paintings collected in Australia. Although he is said to have 'achieved particular note' with the expedition to 'primitive Arnhem Land', a more sober assessment would recognise that his time in Australia was something of a deviation in a career otherwise dedicated to North American anthropology and archaeology. ${ }^{29}$ His work on Hopewell Mounds, the earthworks indigenous to the Midwest and south-east United States, was his major contribution to the discipline, according to the International Dictionary of Anthropologists. ${ }^{30}$ In Australia, Setzler's work is not well known, although his reports on his 1948 excavations, co-authored with F. D. McCarthy (who represented the Australian Museum on the Arnhem Land Expedition), should be recognised as something of a milestone in the development of professional archaeology in Australia. Recent historical interest in intercultural research has kindled some renewed

\footnotetext{
27 Academic record of Frank Maryl Setzler, Office of the Recorder, University of Chicago. A search of other university records reveals that Setzler was awarded an Honorary Doctorate of Science by Indiana University in 1971.

28 'Frank Setzler, Biographical File' RU 7098, Smithsonian Institution Archives, Smithsonian Institution, Washington DC.

29 'Anthropologist Frank M. Setzler Dies', Washington Post, 20 February 1975.

30 James R. Glenn, 'Frank M. Setzler', in International Dictionary of Anthropologists, ed. Christopher Winters (New York: Garland Publishing, 1991), 633.
} 
interest in Setzler's non-American investigations. Michael Davis pays detailed attention to Setzler and his collaborators in his 2007 study of the depiction of Indigenous heritage in European-Australian writings and my own work has addressed the motivations for his appointment to the expedition and the longterm impact of his osteological collecting. ${ }^{31}$

By the end of 1948, there was little love lost between Setzler and Mountford. Arguments about the carve-up of collections between institutions - especially the bark paintings that Mountford valued so highly-had taken a heavy toll on their relationship. Setzler's sense of professional superiority over the self-taught Mountford further contributed to the differences between them. Yet in spite of their contrasting experiences in terms of education and employment, there are interesting parallels in the careers of the expedition leader and his deputy. Setzler's engagement with Aboriginal Australia, including his circulation in the US of photography and artefacts acquired in Arnhem Land, won him a degree of celebrity that he had never previously enjoyed. The vehicle for this was the Arnhem Land lecture film, officially titled Aboriginal Australia, which had its first major screening in 1950 when it was shown to 3,800 members of the NGS in Washington's Constitution Hall. ${ }^{32}$ Word of the film spread and Setzler engaged an agent who for several years secured him bookings on the US lecture circuit, providing a tidy supplement to his Smithsonian salary. Having fallen into the hands of publicists, the lecture film's benign if unexciting title, Aboriginal Australia, was supplanted by more florid descriptors. When it became part of the 'World Adventure Series', hosted by the Detroit Institute of the Arts, the show was dubbed 'Australia's Stone Age Tribesmen'. As was the case with Mountford's films, the thrill of the primeval was the principal point of interest in a market already cluttered with exploration and adventure. Key aspects of Setzler's presentation, highlighted in a promotional brochure, included: 'Clay-smeared primitive natives'; 'The Blood Feud ceremony'; 'Eating insects'; 'Shooting big crocodiles'; 'The Stone Age native at home'; and 'Weird rites'. ${ }^{33}$

When Setzler first joined the Smithsonian he fell under the influence of Aleš Hrdlička, the founder and veteran Curator of Physical Anthropology at the US National Museum. A prolific writer, lecturer and racial theorist, Hrdlička was internationally recognised in the field of physical anthropology.

\footnotetext{
31 Michael Davis, Writing Heritage: The depiction of Indigenous heritage in European-Australian writings (North Melbourne: Australian Scholarly Publishing and the National Museum of Australia Press, 2007), 182212; Martin Thomas, 'Expedition as Time Capsule: Introducing the American-Australian Scientific Expedition to Arnhem Land', in Exploring the Legacy of the 1948 Arnhem Land Expedition, eds Martin Thomas and Margo Neale (Canberra: ANU E Press, 2011), 1-30; and Martin Thomas, 'Because It's Your Country: Death and its meanings in west Arnhem Land', Life Writing, (2013), http://www.tandfonline.com/doi/abs/10.1080/.VA5$4 \mathrm{Cg} 4 \mathrm{Z} 4 \mathrm{~g}$.

32 Lectures on 'Aboriginal Australia', Lectures National Geographic Soc, Box 20, Frank Maryl Setzler Papers $1927-1960$

33 Brochure in Setzler, Lectures 1951, Box 20, Frank Maryl Setzler Papers 1927-1960.
} 
A man thoroughly steeped in the eugenic theory that held such sway in the early twentieth century, he is widely regarded as the patriarch of physical anthropology in North America. When Hrdlička died of a heart attack in 1943, Setzler was sufficiently close to him to serve at his funeral as a pallbearer. ${ }^{34}$ Hrdlička is relevant to this discussion for a number of reasons. Firstly and generally, his preoccupation with the origins of humanity, which inspired his interest in collecting and analysing the bones of various peoples from around the world, emphasises the embedded trans-nationalism of the quest to understand the origins of humanity and its development. Secondly, but just as important, is the personal and professional influence of Hrdlička upon his younger colleague. Hrdlička was the 'founding father' of the collection into which the bones from Arnhem Land were accessioned. So some understanding of his career gives significant context to Setzler's activities in Australia (where Hrdlička himself did research in the 1920s).

Born in Bohemia, Hrdlička migrated with his family to New York when he was thirteen. He qualified in medicine and served his internship at the State Homeopathic Hospital for the Insane in Middletown, New York. It was there, working daily with psychiatric patients, that he began his investigations in physical anthropology. Dealing in his medical practice with the 'abnormality' of the insane, he embarked on a sustained quest to establish baseline 'normal' human physiology. This he identified in the skeletal structure of what he dubbed the 'Old Americans': whites of European descent whose ancestors had resided in the US for at least two generations. ${ }^{35}$ Much of his work concerned the physiology of contemporary humans and its relationship to earlier forms of hominid physiology, as determinable from archaeological evidence. When recruited to the Smithsonian in 1903, he made it his mission to dramatically expand his department's collection of human remains, which then consisted of some 2,200 skulls. During Hrdlička's tenure, transfers from other anatomy collections were negotiated and he led expeditions of his own, collecting with gusto. In his forty years at the Smithsonian, he grew a collection that has been described as 'a great scientific assemblage'. ${ }^{36}$ By the time of his retirement it contained bones and soft tissue from more than 10,000 individuals. As detailed below, Setzler himself contributed to the collection through the excavation of Native American burial sites.

Hrdlička's short visit to Australia in mid-1925 was part of an international study tour that involved excavation and collection-based research, as well as a

34 'Dr. Hrdlicka Funeral Rites To Be Today', Washington Post, 8 September 1943.

35 Linda Magaña, Mr. America's Creator: The race science of Dr. Ales Hrdlicka, 1896-1943 (Undergraduate Thesis, Columbia University, 2011), 45.

36 Stephen Loring and Miroslav Prokopec, 'A Most Peculiar Man: The life and times of Aleš Hrdlička', in Reckoning with the Dead: The Larsen Bay repatriation and the Smithsonian Institution, eds Tamara L. Bray and Thomas W. Killion (Washington and London: Smithsonian Institution Press, 1994), 27. 
good deal of spruiking for his discipline. At Jersey and Broome in north-west Australia he visited Aboriginal communities where he measured people and made observations on physique, skin tone and hair colour. In the United States, where his presence as a fieldworker has been closely scrutinised, Hrdlička is said to have had a 'gruff and belligerent manner of dealing with native people', especially when - as happened on occasion - they confronted him about his excavation of mortuary sites. ${ }^{37}$ His relationships with Aboriginal Australians seem to have been no less cursory. Of his encounter with some Aboriginal South Australians, he remarked that they 'beg with no more shame than so many monkeys'. ${ }^{38}$ Although he did argue that Australia should 'set aside regions in which the natives could be kept from contamination by the whites', he did so only to prevent 'this most interesting race' being 'lost to science and to the world, in the course of a few years' ${ }^{39}$

Gregory Smithers, a historian of race and racism, has argued that Hrdlička's thoughts on the Indigenous peoples of both North America and Australia are emblematic of a paradox deeply inscribed in the racial thinking of his era. Hrdlička positioned himself as an enemy of racial discrimination, but claimed that the key to abolishing it was the elimination of racial difference by the breeding out of colour. ${ }^{40}$ While in Australia, he made detailed examination of osteological collections, both public and private, ever determined to chart the distribution of racial difference and theorise its origins in terms of evolutionary history. Hrdlička's temperament, as described by the New York Times, was 'intense, leonine and picturesque'; his platform manner was 'both disarming and impressive'. ${ }^{41}$ Australian pressmen were similarly in awe of the visiting American, who made numerous public appearances. It was reported that he measured 1,000 Aboriginal crania in the course of his visit. During his Australian tour he negotiated the acquisition of some human remains for the Smithsonian collection. Records in Washington establish that at Hrdlička's behest, the Public Library, Museum and Art Gallery of Western Australia sent to the Smithsonian Institution some seventy items of ethnological interest, including '[b]ones of two incomplete skeletons from a tree burial' originating from near Derby in the Kimberley. The Western Australian curator hoped that in exchange the Smithsonian would supply his collection with samples of South American ceramics and a series of North and South American scorpions. ${ }^{42}$

\footnotetext{
37 William W. Fitzhugh, 'Foreword', in Reckoning with the Dead: The Larsen Bay repatriation and the Smithsonian Institution, eds Tamara L. Bray and Thomas W. Killion (Washington DC and London: Smithsonian Institution Press, 1994), viii.

38 Cited in Gregory D. Smithers, 'The Dark Side of Anti-Racism: "Half-breeds" and the anthropology of Aleš Hrdlička', Transnational Subjects: History, science and culture 1:1 (2011): 74.

39 Hrdlička quoted in 'Ancient Man', Mercury (Hobart, Tas.), 9 January 1926.

40 Smithers, 'The Dark Side of Anti-Racism'.

41 'Dr. Ales Hrdlicka, Anthropologist, 74', New York Times, 6 September 1943.

42 'United States National Museum Accession Memorandum, Department of Anthropology, Division of Physical Anthropology', RU 305, Accession File 94717, Office of the Registrar, Smithsonian Institution
} 
Hrdlička visited a range of Australian institutions. At the South Australian Museum more than 600 skulls and other skeletal material were made available for him to examine. He promulgated the view that the Australian and Tasmanian Aborigines were a 'fundamental race' that represented 'a paleolithic stage of stone culture'. In championing his line of research, he explained that the cardinal objective of physical anthropology was to understand the origins of 'ancient man and fossil apes'. In discussions with journalists, he gave detailed accounts of famed excavations of the period, all of which yielded osteological evidence of the human form in earlier stages of development. ${ }^{43}$

The claim that his research might answer the great questions of human origin, and the imputation, in his dealings with the public, that the bones of interest to archaeologists were those of great antiquity, was for Hrdlička a standard rhetorical gambit - one that is indicative of a considerable disjunction between theory and practice. If it really had been true that physical anthropology was only interested in the earliest examples of humans and their antecedents, and confined the scope of its collecting accordingly, then it is likely that the great animus towards his collections, felt especially strongly by Native Americans, would be less intense. But physical anthropology did not-and arguably could not - confine itself to cherry picking from the archaeological record the ancient skulls that became celebrity objects in the history of paleontology. Such a collection, bereft of recent examples of human physiology, would have been of little practical use to Hrdlička and his peers. Being a comparative discipline, physical anthropology required a range of specimens from across the spectrum of human history. That much was essential if an evolutionary sequence was to be established. For that reason it was necessary for Hrdlička to pursue strategies of collection building that threw his own personal ambitions-inseparable as they were from the collective ambition of scientific advancement - into direct conflict with the localised knowledge systems of those allegedly primitive societies, the great majority of which continued to suffer an extraordinary level of disempowerment as a result of their colonial past.

In her study of human dissection in Britain and Australia, historian Helen MacDonald draws connections between nineteenth-century medical research, the collecting of bodies and body parts, and notions of criminality. While cadavers of condemned felons were made available to surgeons for the purpose of study and teaching, the relative scarcity of executions in Britain notoriously resulted in the blackest of black markets: an illicit trade in corpses, acquired from unscrupulous undertakers or stolen from fresh graves. ${ }^{44}$ In the clash

Archives, Washington DC. This record contains an internal memorandum from Hrdlička dated 3 November 1926 stating: 'This is an exchange with the Perth Museum which I have arranged during my visit to Australia.'

43 'Australian Blacks' Origin', The Mail (Adelaide, SA), 6 November 1926.

44 Helen MacDonald, Human Remains: Episodes in human dissection (Carlton: Melbourne University Press, 2005). 
between indigenes and colonisers, there was frequent conflation of the primitive and the criminal. Those who killed in defence of their territory were described as 'murderous' and it is hardly incidental that the heads of many warriors who died for their cause became specimens in museums or private collections. The process of 'desubjectification' that occurred here was of course dependent upon political and cultural processes that targeted particular social or ethnic groups for objectification. Any pretence that science was objectively removed from these processes is of course an absurdity. It both benefited from, and contributed to, this history. Hrdlička, for example, drew personal profit from his oft-made claim that certain branches of humanity were Paleolithic survivals in which science had a special interest. Such arguments from such a source gave scientific validation to the differential treatment of these peoples on the part of those who governed them.

Indigenous societies in twentieth-century Australia, like those in so many parts of the world, existed within the strictures of an elaborate web of ordinances, threats and strategies of containment, collectively intended to manage, administer and curtail their livelihoods, and to legitimise the exploitation of their ancestral Country. At the time of Hrdlička's visit to Australia, Aboriginal people were not counted in the national census and were prevented from enrolling as voters. These were among a suite of measures that for the most part excluded them from the citizenry. When, as had been happening intermittently since the nineteenth century, outsiders arrived to ransack cemeteries or other mortuary sites, the affected communities had little recourse, legal or otherwise. In some jurisdictions in the years when bone taking was particularly rife, Aboriginal burials were covered by laws for the protection of graves - although prosecution of thieves was rare or non-existent. ${ }^{45}$ In South Australia, the state's sense of proprietorship over Aboriginal land and culture extended to the bodies of the deceased. Hrdlička approvingly told a journalist that the osteological collection in Adelaide had grown rapidly as the result of 'a beneficial law, which obliges all police officials of the State to forward to the Museum any aboriginal skeleton remains that may be found'. ${ }^{46}$

In contradistinction to his public pronouncements, the archaeological culture fostered by Hrdlička encouraged the exhumation of a great many burials that were historically recent. His fieldbooks from Alaska reveal horrific incidents.

45 Paul Turnbull, 'Indigenous Australians and Native Title', in The Dead and Their Possessions, eds Cressida Fforde, Jane Hubert and Paul Turnbull (New York: Routledge, 2004), 83.

46 'Australian Blacks' Origin', The Mail (Adelaide, SA), 6 November 1926. The 'beneficial law' mentioned probably refers to a memorandum from the South Australian Commissioner of Crown Lands to the Chief Secretary: "The recent discovery of the remains of aboriginal natives at the River Murray has brought to my mind the fact that all such remains on Crown lands belong to this department. I shall be obliged if the Hon. Minister will give instructions to any field officers in his department that should they at any time discover human remains, or any articles that have been in use by aboriginals, or any other article of use on Crown lands, they will at once take possession of the discovery, and telegraph your office for instructions as to its disposal.' South Australian Police Gazette, no. 18, 3 May 1911. Thanks to Paul Turnbull for sharing this information. 
On one occasion he was forced to abandon an exhumation because the body was 'too fresh'. In 1926 on the Yukon River he was nearly intercepted by mourners of the person whose skeleton he had loaded into a boat. As he and his assistant fled the scene, an 'old Indian and his crone' stood watching. 'They know already', he recorded. ${ }^{47}$ Frank Setzler began working alongside Hrdlička a few years after this incident occurred, and he too began to contribute to the osteological collection. Writing from Comstock, Texas, in 1933, he described an extensive excavation performed in a large cave containing substantial evidence of Native American occupation. The site yielded 'nearly 500 recorded specimens and over a dozen burials'. The survival in good condition of fibre matting in the cave and a fur robe draped over one of the bodies suggests that they were not of great antiquity. ${ }^{48}$ The same can be said of the burials that he disturbed in Arnhem Land, as the film footage, in which he is seen unwrapping a jawbone from a cloth surround, makes clear.

\section{Setzler and the Theft}

It was six years after the expedition that the first of the four volumes of Records of the American-Australian Scientific Expedition to Arnhem Land was published. Volume 1, titled Art, Myth and Symbolism (1956) and written solely by Mountford, began with an essay titled 'The Story of the Expedition'. He summarised their collective achievement as follows:

The results of the expedition could hardly have been richer, both from the standpoint of human companionship and scientific results ... The gross results of the collections, too, were impressive: 13,500 plant specimens, 30,000 fish, 850 birds, 460 animals, several thousand aboriginal implements and weapons, together with photographs and drawings of a large number of cave paintings ... There was also a collection of several hundred aboriginal bark paintings and two hundred string figures. In addition to the physical collections of natural history and ethnological specimens, each scientist had written extensive field notes as a basis for his scientific papers. There were also many hundreds of monochrome and coloured photographs as well as several miles of colour film on aboriginal life and natural history. ${ }^{49}$

\footnotetext{
47 Cited in Gordon L. Pullar, 'The Qikertarmiut and the Scientist: Fifty years of clashing world views', in Reckoning with the Dead: The Larsen Bay repatriation and the Smithsonian Institution, eds Tamara L. Bray and Thomas W. Killion (Washington DC and London: Smithsonian Institution Press, 1994), 21-2.

48 Setzler to Wetmore, 28 April 1933, Alexander Wetmore Papers, c. 1848-1979, RU 7006, Box 60, Smithsonian Institution Archives, Smithsonian Institution, Washington DC.

49 Charles P. Mountford, Records of the American-Australian Scientific Expedition to Arnhem Land: Vol. 1: Art, myth and symbolism (Melbourne: Melbourne University Press, 1956), xxx.
} 
This list is revealing - for its exclusions as much as its inclusions. Not until 1960, when Volume 2 of the Records appeared, was the collection of human remains officially acknowledged in Australia. McCarthy and Setzler's jointly authored contribution to that volume, titled 'The Archaeology of Arnhem Land', did discuss the bone taking, but it was well after the event. This is a substantial, eighty-page paper that provides detailed evidence of the archaeological work performed by the expedition including descriptions of most sites from which human remains were collected.$^{50}$ Further detail is contained in Setzler's fieldbooks, held by the Smithsonian's National Anthropological Archives, and in a list of physical anthropology specimens, prepared in Washington when they were accessioned into the US National Museum. ${ }^{51}$ These records establish that the bones originated from three sites on Groote and nearby islands; one site on the Gove Peninsula in north-east Arnhem Land; one site from the island of Milingimbi (although the bones are said to have been transported there from mainland Arnhem Land); and three sites in the vicinity of Gunbalanya. Notably, not all the bones collected were of people indigenous to Arnhem Land. Graves of three mariners from South Sulawesi, who had died while harvesting trepang, were excavated from Groote Eylandt. Another two males who were reputedly murdered by Aborigines in 1916 - one of mixed European-Aboriginal ancestry and the other Asian-were excavated and collected at Port Bradshaw on the Gove Peninsula. ${ }^{52}$ Of the Aboriginal remains, some 170 bones were inventoried as individual items. Others were registered as bundles of bones or as packets of fragments. They included pieces of skull from at least three people; bones of at least five children (including two babies) that were wrapped in paperbark bundles; and assorted 'skeletal parts' of at least one other person. The number of bones collected from such a range of sites makes it plain that for Setzler, and to a lesser extent McCarthy, the collection of human remains was a major part of the work conducted in Arnhem Land. Other members of the expedition came to regard it as Setzler's signature activity - to the extent that it was caricatured in doggerel songs that were performed in evening singalongs. ${ }^{53}$ In lyrics set to the melody of Ain't Gonna Grieve My Lord No More, expedition members sang of their deputy leader:

\footnotetext{
50 Frederick D. McCarthy and Frank M. Setzler, 'The Archaeology of Arnhem Land', in Records of the American-Australian Scientific Expedition to Arnhem Land: Vol. 2: Anthropology and nutrition, ed. Charles P. Mountford (Melbourne: Melbourne University Press, 1960), 215-95.

51 'List of Specimens Collected by F. M. Setzler, Australia, 1948', Arnhem Land Expedition, RU 305, Accession File 178294, Smithsonian Institution Archives, Smithsonian Institution, Washington DC.

52 Patrol officer and writer William E. Harney (official guide on the 1948 expedition) was the source of information about the death of these men. See 'Notes on the human skeletal material recovered in Arnhem Land, northern Australia, in 1948, by F. M. Setzler', Arnhem Land Expedition, RU 305, Accession File 178294, Smithsonian Institution Archives, Smithsonian Institution, Washington DC.

53 See Harris, this volume.
} 
There's no room in Heaven

For a man like Frank,

To exhuming skulls

Is what he sank. ${ }^{54}$

This is not the only occasion where bone theft was treated as an object of mirth. A photograph of Setzler 'discovering' a crevice containing a human skull and other bones was reproduced in a National Geographic article with a caption that begins: 'Alas, Poor Yorick! Alas, Poor Setzler!'55 Published in 1949 and titled 'Exploring Stone Age Arnhem Land', this was the most extensive of several articles published in the magazine as a result of the expedition. Mountford wrote the text, but as was customary at the Geographic, the selection of photographs and drafting of the captions or 'legends' were done in-house. National Geographic Society records establish that Howell Walker wrote all the legends and, with input from Setzler, also played a major role in editing the article. ${ }^{56}$ Mountford's leadership had been the cause of great acrimony during the expedition, to the extent that the Department of Information attempted (unsuccessfully) to depose him as leader when they were stationed at Yirrkala, their second base. ${ }^{57}$ Walker and Setzler both had ill feelings about his leadership and they gleefully embraced the opportunity to edit his work. Walker told Setzler that his editor had given them 'carte blanche to butcher, build, destroy or do anything to improve' Mountford's 'unmasterpiece'.$^{58}$

The fault-lines of the expedition-resulting as they did from an array of national, cultural, disciplinary and interpersonal differences-are manifest in that National Geographic article, which deceptively presents as the initiative of a single author, though it is really a composite creation, as the behindthe-scenes wrangling makes clear. In any case, the visual component of the article-long recognised at the Geographic as having much more impact than the printed word - was the work of Walker, aided and abetted by Setzler and the editorial executives who played a major role in selecting images for publication from the thousands shot in Arnhem Land. The depiction of Setzler in his glory as the discoverer of bones is one of various tensions between the written and visual narratives. Like 'The Story of the Expedition', the written text of 'Exploring Stone Age Arnhem Land' omits mention of bone taking, even when it summarises Setzler's archaeological work at Injalak. Mountford would

54 'I ain't gunna [sic] grieve' (unattributed lyrics), Frank M. Setzler, Arnhem Land Exped. Corresp. 1948-9, Folder 2, Box 7, Frank Maryl Setzler Papers 1927-1960.

55 Charles P. Mountford, 'Exploring Stone Age Arnhem Land', National Geographic Magazine 96:6 (1949): 778.

56 'Memorandum from J. R. Hildebrand', 12 September 1949, Manuscripts Accepted, Exploring Stone Age Arnhem Land, Mountford, Charles P., Microfiche Archive \#510-1.3249, Archives and Records Library, National Geographic Society (NGS), Washington DC.

57 See Jones, 'Inside Mountford's Tent', and Thomas, 'A Short History of the 1948 Arnhem Land Expedition'. 58 Walker to Setzler, 9 September 1949, 'National Geographic Society Correspondence 1948-49', Box 32, Frank Maryl Setzler Papers 1927-1960. 
have his reader believe that the yield of those excavations was confined to 'a complete series of projectile points, adze stones and quartzite scraper' ${ }^{59}$ I quote here from the manuscript of his first draft, for the passage cited was entirely eliminated from the published version. The closest he came to the subject of burial was an account of a night in a cave where he slept near the scattered bones of a skeleton. This passage did make it to publication and it appeared under a subheading, 'Slept Next to Human Skeleton' ${ }^{60}$ Mountford's reticence on this matter is apparent in many other documents, including his final report on the expedition to the Department of Information. ${ }^{61}$ 'Discovery' was of course a key trope in the many cables and press releases that he issued during the expedition to advertise their accomplishments, but the discussion of human remains was usually suppressed or, on rare occasions, acknowledged in heavily coded language. Specific mention of the removal of bones was assiduously avoided, as can be seen in a press release where Setzler is said to have 'unearthed several strange types of burial, and discovered many human skeletons in the clefts of the rocks' ${ }^{62}$

While Mountford himself seems not to have participated in the plunder of mortuary sites, he made no effort to prevent it happening. As the leader he had the power to do so and as someone with long experience of Aboriginal society, he would - or should-have known that it would cause deep and lasting offence. Some explanation for Mountford's position on this matter can be found in the aforementioned fault lines, which became manifest in a series of disputes between him and others in the expedition, especially Setzler and McCarthy. While personality differences and condescension towards Mountford's supposed amateurism were certainly at work here, the principal point of contention, often mentioned in the expedition diaries, concerned the division of the ethnographic collections that were being amassed. Mountford, who hoarded bark paintings with something close to fetishism, resented the claims of his colleagues upon those collections. The friction generated was considerable, for as curators doing extended fieldwork on full salary, Setzler and McCarthy were expected to return to their home museums with substantial riches in terms of collections. Mountford, who had no interest in physical anthropology, was prepared to let

\footnotetext{
59 C. P. Mountford, 'The Arnhem Land Expedition' (draft), Manuscripts Accepted, Exploring Stone Age Arnhem Land, Mountford, Charles P., Microfiche Archive \#510-1.3249, Archives and Records Library, NGS, 36.

60 Mountford, 'Exploring Stone Age Arnhem Land': 779

61 Mountford, 'The Report of the Origin, Objects Activities and Results of the ... Expedition to Arnhem Land', Reports of Staff, PRG 1218/17/17, Mountford-Sheard Papers, American Australian Scientific Expedition to Arnhem Land 1948, SLSA.

62 Press release signed by Mountford and received by the Northern Territory Administrator on 25 October 1948, 'Scientific Expedition to Arnhem Land \& Northern Territory - C. P. Mountford', Correspondence files, Northern Territory, F1, Item 1945/151, National Archives of Australia (NAA), Darwin.
} 
Setzler collect bones, hopeful that the acquisition of these trophies would lessen his requirement for the types of object - particularly the bark paintings - that Mountford so coveted.

There is nothing to suggest that Mountford's covering up of the bone taking was due to regret at its happening. More likely it was because Setzler was planning to take his prizes abroad. Mountford had made many enemies in the course of his career and his antennae were habitually attuned to those who could do him harm. Few white people at that time thought to challenge the pillaging of burial sites for the offence it gave to Aboriginal people, but the export, if it became known, could be queried on nationalistic grounds - the argument being that objects significant to Australia's heritage should go to an Australian museum. Moreover, Mountford had brokered an agreement that all type specimens collected on the expedition would remain the property of Australian institutions, while the 'ethnological material' would be divided between Setzler, McCarthy and himself. ${ }^{63}$ Concerning the skeletal collections, it was eventually decided at the Australian end (long after the export to the US) that two-thirds of them should be housed in Australian collections. ${ }^{64}$ Correspondence dating from the period when the expedition was wrapping up reveals sensitivity about the export of collections. Walker reported that there was anxiety among expedition members about whether cases of specimens, intended for the Smithsonian, would, on inspection, be blocked from leaving Australia by local authorities. ${ }^{65}$ An indication that they were eager to get the bones out of the country as discreetly as possible is reflected in documentation pertaining to the freight of cases bound for the US. The bones were part of this consignment, but the contents are ambiguously described as 'Natural History Specimens' ${ }^{66}$

Setzler, as we know, was anything but coy about the bone taking once he returned home and began his film lectures, but it is possible that Mountford put pressure on him to keep quiet about the business while on Australian soil. Setzler's own final report on his research, intended for Australian authorities,

63 Mountford put this proposal to Alexander Wetmore, Secretary of the Smithsonian, in a letter dated 3 February 1948. Wetmore confirmed agreement on 9 February 1948. Correspondence in RU 305, Accession File 178294, Smithsonian Institution Archives, Smithsonian Institution, Washington DC..

64 May, Collecting Cultures, 191.

65 Howell Walker, who assumed responsibility for overseeing shipping arrangements, reported to his superiors in Washington of the 'possibility that Australian Department of Internal Affairs might examine all cases of specimens with view to holding in Australia any specimen not in duplicate. But the Department of Information is trying to iron this business out with the Department of Internal Affairs, pointing out that an earlier decision not to examine the cases had been reached. McRae will keep us advised.' Walker to Melvin M. Payne, 2 April 1949, Setzler, 'National Geographic Society Correspondence 1948-49', Box 32, Frank Maryl Setzler Papers 1927-1960.

66 Northern Territory Administration to Department of Information, 19 January 1949, 'Arnhem Land Expedition: C. P. Mountford', General correspondence files, two number series, Department of Information, 
does acknowledge that human remains were encountered, but refers to their collection only implicitly - as his description of excavating at Injalak makes plain.

Ten distinct sites were selected ... These produced hundreds of quartzite scrapers, hematite stones with rubbed faces as a result of use for obtaining their red ochre used in making the cave paintings, uniface and biface chipped projectile points, human burials, glass beads, pieces of iron, etc. ${ }^{67}$

The language used here is fascinating. The burials are themselves buried in the mass of other data; their unburying is attributed not to the writer but to the sites themselves that are said to have 'produced' the archaeological haul. Nowhere in this report does Setzler admit to disturbing the deceased. He preferred a passive voice for these sections of his report: 'Here before us, overlooking the sea, were many skulls and skeletons'; or, more actively, though not confessing to the act of removal: 'We were most fortunate in finding the well preserved skeletons, extended full length'. This is otherwise atypical of Setzler's reporting, where his own agency is strongly emphasised.

[M]y program called for various anthropological approaches. These included the taking of palm and finger prints, testing their taste buds, collecting hair samples, photographing their heads, the making of facial casts and anthropological measurements, studying their material culture $\ldots$ and archaeological investigations. ${ }^{68}$

When he returned to Washington DC, Setzler wavered in his choice of euphemism for describing the thefts. 'Collecting' was probably the most common, though in the film lecture he spoke of the bones being 'preserved' in his museum. Even more intriguingly, he would claim that the bones had been 'recovered' when he removed them from the rock or ground. ${ }^{69}$ The displacement of the theft became a restitution; a return to their rightful place.

Am I being too harsh in describing the bone collector as a thief? Should I recognise that according to his own way of thinking, he was not stealing but 'recovering' perishable evidence in the service of a beneficent science? I say no to this question because I am convinced that Setzler knew perfectly well that he was stealing. So detailed are his fieldbooks that they allow his moral workings, such as they are, to be at least partially recovered. On 7 October 1948, he made an initial visit to Gallery Hill, as he called Injalak, to survey sites for the

67 Memorandum from Setzler to Mountford, 4 November 1948, Reports of Staff, American Australian Scientific Expedition to Arnhem Land 1948, PRG 1218/17/17, Mountford-Sheard Papers, SLSA.

68 ibid.

69 'Arnhem Land Ethno Objects', Box 23, Frank Maryl Setzler Papers 1927-1960. 
excavations that would dominate the weeks to come. He was accompanied by two young men employed as assistants. Aged in their teens, they resided at the cultural melting pot that was Oenpelli Mission, already occupied by Aboriginal people from a myriad of clans and language groups. One of the assistants was identified only as Micky, a name likely to have been bestowed by missionaries. The other can be firmly identified as Jimmy Bungaroo, who later in his life would become a well-known personality in Maningrida, a large settlement east of Oenpelli (see Figure 6).

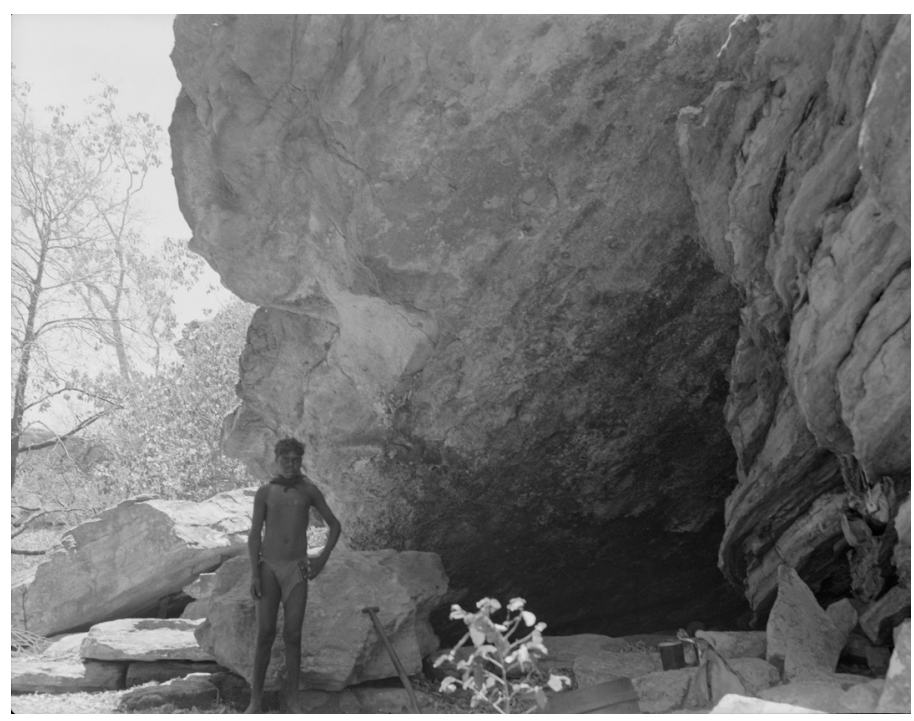

Figure 6: Jimmy Bungaroo at Injalak on the outskirts of Gunbalanya (Oenpelli Mission) during the American-Australian Scientific Expedition to Arnhem Land, 1948. Photograph by Frank Setzler.

Source: By permission of the National Anthropological Archives, Smithsonian Institution. Photo Lot 36 Oenpelli_053.

Composed of heavily weathered sandstone, the boulderous rise that is Injalak is defined by its many gaps, cracks, fissures, overhangs and deeper passages leading into caves. The latter are often referred to as galleries - rightly so, for they are full of art. Said to have been created by a fish, the Long Tom, when he leapt from the billabong at its base, Injalak is a natural dwelling place, traditionally occupied in the wet season when the movement of Bininj (as the local Aboriginal people call themselves) was greatly curtailed by the swelling of the rivers and the inundation of the flood plains. A rich sequence of rock paintings, created over centuries, can still be seen. The debris of habitation provided material that Setzler would excavate and sieve as part of his research program. The former residents of these caves were evidently at home living in close proximity to the 
mortal remains of their ancestors. As is the case throughout the plateau country of Kakadu National Park and west Arnhem Land, the crevice-ridden sandstone of Injalak served as a natural ossuary. Funerary rites in this region required sequences of ceremony, sometimes lasting several years, of which the Lorrkon or 'hollow log rite' is best known. ${ }^{70}$ Each stage of memorialisation involved caring for the remains of the deceased in a particular way. At the conclusion of the rites, the bones - by this time coloured with a solution of red ochre and wrapped in sheets of the pliant paperbark that grows abundantly in this region - were placed in perpetuity in caves or crevices. With the deterioration of the bark over time, the bones would spill from their wrappings, serving as a visible reminder of the enduring presence of ancestor spirits.

Setzler was in the company of one of his Aboriginal assistants when he made the initial survey of Injalak. He entered a large cave that is readily identifiable and where some human remains can still be seen. There were many more bones when Setzler first went there. He described in his notebook how '[o]ne skull and accompanying long bones have a dark red pigment well preserved over them. I paid no attention to these bones as long as the native was with $\mathrm{me}^{\prime} .{ }^{71}$

Setzler's own record of his archaeological work around Injalak and the nearby hill, Argaluk (an important ceremonial site), establishes that he consistently avoided the scrutiny of his assistants or of any other Aboriginal people when he collected human remains. Of bones stolen on 28 October (the same day he filmed with Walker, although this appears to have been a separate incident), he writes of Bungaroo and Micky:

During the lunch period, while the two native boys were asleep, I gathered the two skeletons which had been placed in crevices outside the caves. These were disarticulated ... and only skull and long bones. One had been painted with red ochre. These I carried down to the camp in burlap sacks and later packed in ammunition boxes. ${ }^{72}$

Setzler's surreptitiousness leaves little doubt of his awareness that this was theft. He waited for Jimmy and Micky, who had been labouring since dawn in the heat, to take their siesta before doing the deed. Similarly, no Aboriginal people are present in the film of him taking the bones. The timing of the event-late October-is itself notable, for it was just days before the expedition shipped out. By delaying the act until the final possible moment, Setzler reduced his

70 See Ronald M. Berndt and Catherine H. Berndt, Man, Land and Myth in North Australia: The Gunwinggu people (Sydney: Ure Smith, 1970), 133-5.

71 Mountford 'Diaries 1948', Box 14, Frank Maryl Setzler Papers 1927-1960, 7 October 1948.

72 Mountford 'Diaries 1948', Box 14, Frank Maryl Setzler Papers 1927-1960, 28 October 1948. 
chances of being challenged by the traditional owners of the site. The stealth continued as the bones were sealed in boxes, shipped to Darwin then Sydney, and spirited out of the country.

Setzler was the most assiduous body snatcher on the Arnhem Land Expedition, but he was not the only one. As noted, McCarthy assisted him in excavating and collecting human skeletons. By the end of the expedition, bone collecting had become normalised - a mere extension of the natural history collecting that continued throughout. The expedition included a botanist, a mammalogist, an ichthyologist, and an ornithologist. Between them, these men amassed tens of thousands of specimens. John Bray, a farmer and former serviceman, was an employee of the expedition. Recruited as the cook, he became the transport officer when that position fell vacant. ${ }^{73}$ An interest in insects inspired him to start collecting, to the extent that he was recognised in the expedition Records as 'honorary entomologist'. ${ }^{74}$ His diary records how he worked with McCarthy in excavating what seemed to be a woman's skeleton, lodged in a cave near Kunnanj or Fish Creek, a site beyond Oenpelli where he and other expedition members were stationed. ${ }^{75}$

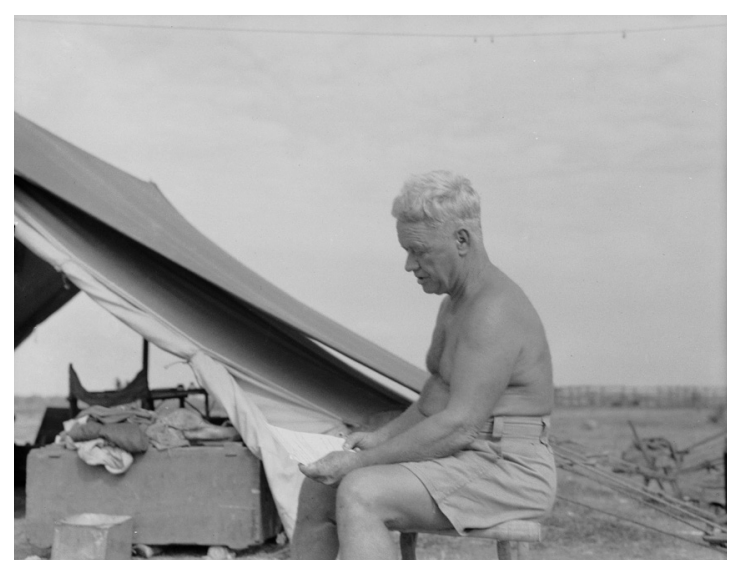

Figure 7: W. E. Harney at Gunbalanya (Oenpelli Mission) during the American Australian Scientific Expedition to Arnhem Land, 1948. Photograph by Frank Setzler.

Source: By permission of the National Anthropological Archives, Smithsonian Institution. Photo Lot 36 Oenpelli_143.

73 See Amanda Harris, 'Food, Feeding and Consumption (or the Cook, the Wife and the Nutritionist): The politics of gender and class in a 1948 Australian expedition', History and Anthropology 124:3 (2013): 363-79.

74 Mountford, Records of the American-Australian Scientific Expedition to Arnhem Land, xi.

75 John Bray, 'Arnhem Land Expedition 1948', Private Journal, collection of Andrew Bray, Canberra, 19 October 1948. See Harris, this volume. 
A further skull was collected by W. E. 'Bill' Harney, the expedition's official guide (see Figure 7). Harney is the second white man visible in the film footage, described at the beginning of this chapter. He is seen near the top of Injalak, assisting Setzler as they transport a wooden crate of remains. Harney was a well known character in the Northern Territory: a renowned bushman who had recently retired as Commonwealth patrol officer, a position that required travel among, and extensive liaison with, a wide variety of Aboriginal groups. Fluent in Kriol, he was regarded as the go-to person for access to all things Aboriginal. Since 1943, when he published his first work of non-fiction, Taboo, Harney's renown beyond the Territory had grown. A string of other books, mostly combining memoir and observation on Aboriginal life, followed throughout the years until his death in 1962. Journalists, filmmakers, anthropologists and administrators all made use of him as a cultural intermediary, and it is not surprising that in the early planning stages of the 1948 expedition, Mountford was keen to have him involved. Harney joined the expedition in July 1948.

Harney has been portrayed as a significant ally of Mountford in his long conflict with Professor A. P. Elkin and Elkin's beloved protégés, Ronald and Catherine Berndt. ${ }^{76}$ Occupying the Chair of Anthropology at the University of Sydney, Elkin looked down on Mountford as an amateur interloper. He viewed the whole Arnhem Land Expedition with distrust and distaste. Although Harney was keen to participate in Mountford's expedition, his loyalties lay chiefly with the professor, whom he once lauded in an unpublished poem titled 'To You My Friend' ${ }^{77}$ The pair had corresponded since 1937 and Elkin was seminal in kick-starting Harney's literary career. He liaised with publishers, collected royalties, wrote prefaces, and effectively acted as the bushman's agent in the city. ${ }^{78}$ Harney's references to Mountford were invariably disparaging, to the extent that when he told Elkin he would participate in the expedition as a guide, he said of Mountford that he would 'show him little'. ${ }^{79}$ When Harney joined the expedition at Yirrkala, its second base, Elkin wrote to ask if he could obtain for him 'a good Aboriginal skull with jaw-bone' ${ }^{80}$ In November, once the expedition was over, Harney advised Elkin that 'I have the Aborigine skull you required a good one \& will send it down in a week or so' ${ }^{81}$ The origin of the

\footnotetext{
76 Jones, 'Inside Mountford's Tent', 49.

77 'To You My Friend', Correspondence Files, P. 130, Series 8, File 1/8/2, A. P. Elkin Papers, University of Sydney Archives.

78 Correspondence between Elkin and the Commonwealth Literary Fund reveals how Elkin assisted in the publication of Harney's first book, Taboo (1943). See H. S. Temby (Secretary of Commonwealth Literary Fund) to Elkin, 29 April 1943, ibid. Series 8 of Elkin's papers at the University of Sydney provides extensive evidence of how he advised and acted for Harney. They co-authored Songs of the Songmen (1949), although Elkin's contribution involved editing and rewriting Harney's manuscript.

79 Harney to Elkin, 4 January 1948, Correspondence Files, P. 130, Series 8, File 1/8/3, A. P. Elkin Papers, University of Sydney Archives.

80 Elkin to Harney, 6 July 1948, ibid.

81 Harney to Elkin, 17 November 1948, ibid.
} 
skull is not mentioned in the correspondence, but the great abundance of bones around Injalak, and the fact that Harney was helping Setzler collect them, make Oenpelli the likely source.

So noticeable in all these episodes of twentieth-century bone collecting is the great disjunction between the lightness with which it was done and the gravity with which it is regarded in the Aboriginal world. Human matter was a tradeable asset. It could be itemised in a ledger that put it on par with dead scorpions or antique pots. Its acquisition could be laughed at in song, or trivialised in crass literary allusion. In the case of Elkin, there is suggestion that he was after a trophy, seized from under the nose of an expedition leader he clearly despised. The actors in this drama had diverse attitudes to Aboriginal society. Their familiarity with Indigenous people varied enormously. Hrdlička looked down on them from an evolutionary height; Setzler treated them largely as a resource to be mined; Harney positioned himself the 'blackfellow's friend'; Elkin wrote a famous book, The Australian Aborigines: How to understand them (1938). Despite their diversity of experiences and intellectual positions, all saw it as absolutely normal and acceptable that the bones of Aboriginal people were available for the service of their own scientific, pedagogic, or political agenda. The extremity of this objectification - a common thread between all these individuals - becomes utterly clear. So it is the matter of 'subjectification' to which we will now turn.

\section{The View from Gunbalanya}

Beliefs about reincarnation and the origin of spirits among the Gagudju-speaking people of Gunbalanya were described by Baldwin Spencer in Native Tribes of the Northern Territory of Australia (1914), a monograph based on fieldwork in 1912. As he explained it, the Gagadu (spelled 'Kakadu' by Spencer) people of the present are reincarnations of the first people who inhabited the Country. The spirit, known as the Yalmaru, has a cyclical existence, treading back and forth between the worlds of the living and the dead. When a person dies and the mourning ceremonies take place, the Yalmaru watches over the bones in a role of guardianship. With the passage of time, the Yalmaru divides in two. One half remains the original Yalmaru; the other is a discrete though inextricably connected entity, named Iwaiyu. 'The two are distinct and have somewhat the same relationship to one another as a man and his shadow, which, in the native mind, are very intimately associated. ${ }^{\prime 22}$ After a long period of watching over the bones, the time to reincarnate arrives. Iwaiyu assumes the form of a frog who, 
with Yalmaru's aid, finds a woman suitably placed in the kinship system and enters her. Iwaiyu develops into a baby and in this way the spirit returns to the domain of the living while retaining a presence in the world of the dead. ${ }^{83}$

Arnhem Land (a designation created by Europeans for what became a vast Aboriginal reserve) is a mosaic of different cultures, languages and kinship systems. Yet the potency of the spiritual realm and the significance of the human body in beliefs pertaining to the afterlife are common throughout. Like Spencer, the anthropologist Howard Morphy, whose ethnographic research with the Yolngu of north-east Arnhem Land began in the 1970s, describes a belief in 'the existence of two souls or perhaps two dimensions of soul: mokuy and birrimbirr'. After death, 'the mokuy soul goes to part of the clan's territory where mokuy spirits live, and exists there as a ghost'. The mokuy is to do with place, whereas birrimbirr can be thought of as 'the animating spirit effective in a person's conception' ${ }^{84}$ Like the west Arnhem Landers, Yolngu believe that spirits, especially the mokuy part of them, can be harmful to the living. As Reuben Brown notes in this volume, one of the primary functions of funeral rites relates to the journey that a deceased person's spirit takes after death. Mortuary rites serve the living as an expression of respect and an outlet for grief. But more importantly, they guide the spirit through the local topography and allow it to integrate harmoniously with the world from whence it came.

Contemporary beliefs in Gunbalanya, insofar as they have been explained to me, do not exactly equate with Spencer's account. Of course, much has changed in the past century. Gunbalanya was a cattle station and buffalo camp when Spencer visited. In 1925 it was taken over by the Church Missionary Society who developed it into Oenpelli Mission. ${ }^{85}$ The distribution of food from the mission, and changes forced by military presence in the region during the Second World War, encouraged settlement by disparate clan groups from a wide catchment. Today, only a few residents claim lineage with the Gagudju, whose ancestral estates lie to the west of the town, with some falling within the boundaries of what is now Kakadu National Park. Numerically at least, the settlement has long been dominated by speakers of Kunwinjku, a dialect of the language known among linguists as Bininj Gunwok, which until the mid-twentieth century was spoken chiefly around the Liverpool River (near the present site of Maningrida). Christian influence has certainly affected Gunbalanya, but in these syncretic cultures the Bible tends to be regarded as a belief system that sits alongside, rather than overriding, the Aboriginal traditions. So despite the many changes of the twentieth century, there are significant areas of continuity between the

\footnotetext{
83 Spencer, Native Tribes of the Northern Territory of Australia, 271-2.

84 Howard Morphy, Journey to the Crocodile's Nest: An accompanying monograph to the film Madarrpa funeral at Gurka'wuy (Canberra: Australian Institute of Aboriginal Studies, 1984), 40.

85 Ronald M. Berndt and Catherine H. Berndt, Arnhem Land: Its history and its people (Melbourne: Cheshire, 1954), 191.
} 
beliefs articulated by Spencer and those of today. The situation at Gunbalanya resonates with Morphy's observation of the Yolngu that while new ceremonies, some with a Christian origin, have substituted old ones, the contemporary ritual contains significant allusions to past practices. For example, a painted hollow $\log$, once used as a container for bones of the deceased, is still used as a symbolic object in certain mortuary rites, although its function as a coffin has ended. The fusion of old and new custom was fully apparent at Gunbalanya in 2011 when the bones taken by Setzler, after their repatriation in two instalments in 2009-2010, were interred in the ground. Traditional dance occurred in tandem with the Last Rites of the Christian faith. ${ }^{86}$

Despite significant cultural overlaps, the ethnographies point to notable divergences between west and north-east Arnhem Land in relation to beliefs about the attachment of spirits to bones. Environmental differences have played a role in shaping the regional cultures, for west Arnhem Land is plateau and escarpment country where eroded sandstone is a dominant feature of the landscape. In contrast to the beach, swamp and forest of the Yolngu lands, the Bininj estates contain thousands of caves and rock shelters where the bones of the dead can be housed once the mortuary rituals have ended. Morphy says of Yolngu that the effect of funeral rites upon a corpse involve

a series of transformations from a live and potentially dangerous state to a dead and relatively inert state. The body begins as flesh and bones contained within skin, becomes bones within a bark skin, and ends up reconstituted in a dead or inert form, as the bones inside the hollow log coffin. In the meantime, the spiritual components of the dead person have been separated out, the mokuy spirit has dispersed with the flesh, and the birrimbirr spirit has returned to the ancestral domain. The bones have ceased to be the bones of the person and have, to use a Yolngu metaphor, become part of "the bones [ngaraka] of the clan". ${ }^{87}$

For the Bininj-and for many cultures within Aboriginal Australia-the association between bones and spirit is far more enduring than what Morphy describes. What has been communicated to me in talking about these issues, and in being taken to sites where remains were stolen, is that the dead never become objects or object-like. This is a fundamental contrast to the Judeo-Christian tradition where death marks a rupture between flesh and spirit; where the soul goes elsewhere.

\footnotetext{
86 For a description of this ceremony see Martin Thomas, 'Bones as a Bridge between Worlds: Repatriation and reconciliation between Australia and the United States', in Conciliation on Colonial Frontiers: Conflict, performance, and commemoration in Australia and the Pacific Rim, eds Kate Darian-Smith and Penelope Edmonds (New York and London: Routledge, 2015 forthcoming). See also Brown, this volume.

87 Howard Morphy, Ancestral Connections: Art and an Aboriginal system of knowledge (Chicago: Chicago University Press, 1991), 110.
} 
In west Arnhem Land, spirits live in proximity to bones, though they are not embodied within them. Spirits and bones are intimately related. One is immaterial; the other is material. But neither will perish. In this culture, both the living and the dead exist in relation to one another. Being cohabitants in this place-based cosmology, it is only natural that a person's bones should be laid to rest in their ancestral estates. For Bininj, the actions of Frank Setzler were a brazen theft, and it is not really surprising that when the stolen bones were buried on the edge of Gunbalanya in 2011, the chief or 'boss man' who presided over the public mortuary ceremony lectured severely in English: 'Stealing people's bones for study is no bloody good.' But to confine the transgression to the act of theft is to understate the gravity and complexity of the problem. Theft is a crime against property, whereas this was a crime against people. The removal of bones is closer to kidnap from this standpoint. Taking the bones presented Bininj and Aboriginal people from other parts of Arnhem Land with the terrifying possibility that spirits had been wrenched from their Country and taken abroad. Now they must deal with the bewilderment and possible anger of the spirits with their return to Australia.

Hence the role of song and smoke in Washington on the occasion in 2010 when the bones were truly recovered. As clap sticks beat, the contents of the cardboard coffins ended their tenure as museum objects. Recognised again as subjects, they commenced their homeward journey. Song and language guided them again when, a year later, the boxes were opened at Gunbalanya. A group of senior men and women massaged the bones with a solution of ochre. It was a form of 'dressing' as the boss man described it, seated in his wheelchair. Swaddled in sheets of paperbark, the remains were tied into compact bundles. All the while, the boss man spoke to the spirits, assuaging and comforting them. He spoke Kunwinjku, Gagadju, Urningangk, Erre and Mengerrdji-languages that they might have known in life. He introduced himself and he told them where they were. So the process of re-orientation continued as the sound of song and didjeridu led them to the grave. Anger at the theft had not disappeared, but through the labour of caring for the dead, it seemed to have abated.

I do not use the name of the boss man, for he died in the first days of 2012, a terrible though not unexpected loss for all of us who knew him, but especially for his community in Gunbalanya where the young die too often and the elders die too young. ${ }^{88}$ Cultural restrictions on the naming of those who have recently died mean that I can call him only by his 'death name', Nakodjok Nayinggul. I understand that he had cancer and other illnesses, and in the last year of his 
life, when I saw him fairly often, I could tell that the pain was insufferable. We were all aware, though no one was so indelicate to admit, that dealing with the bones returned from the Smithsonian Institution would be his last great work. ${ }^{89}$

Not until the mourning period is over can his name be uttered or his likeness in film or photograph be shown again. In the last year of his life, he and I spoke often to the camera or recorder about the importance of the placement of human remains. His English, acquired from missionaries, was impeccable; he spoke quizzically, and always with measured deliberation.

They would get all bones, they would paint them in either yellow or red ochre, and then they would take them up onto the hill and put them in cave and they would say to them ... in language: "I'll leave you here," and talk to them, and then they would tell them, "Look I'm following you, I'm coming too, so wait for me." And they would put them to sleep then in their own country, in their own territory. Doing all that first, putting someone in the cave, doing that, that was the main traditional owner in there, or elderly person, who was the last one, and then next one took over, maybe his son, and then it went on ... [We do it] not because we love you and we leave you here but because it's your country, we'll come back to you and we'll call out for help if you can help us ...

Having the bones here it means that you've got the man still staying in his own territory ... I can call to him any time because I know he's here. No other questions ... I know he's here, I go to that cave and call out for help. Like somebody might be in danger. That's when you really need someone. So the traditional owner would help and in spirit they would still help. ${ }^{90}$

As these words make plain, the removal of bones fundamentally disrupts the relationship between the dead and those who knew them, whether as living people or as skeletons in a cave. The Bininj, who were known and whose lives were honoured in the rituals that led them to a particular place in their own Country, become a racial type - as posited in someone else's classificatory system. Except in certain enclaves, where physical anthropology collections are jealously guarded and claims for repatriation deflected, bone stealing is no longer seen as such an acceptable sport. Yet the branches of knowledge that took root from these collections, from that transformation of people into objects including the mighty narrative of human evolution-remain very much in vogue.

89 See Thomas, 'Because It's Your Country'.

90 Nagodjok Nayinggul in interview with the author, 9 July 2010. 


\section{Acknowledgements}

Thanks to members of the Gunbalanya community who supported this research and to Margo Daly for research assistance. I am indebted to the two peer reviewers for their close readings and suggestions. My archival research in the US was supported by a Smithsonian Fellowship. Subsequent research was supported by the Australian Research Council (DP1096897 and FT0992291).

\section{References}

Beazley, Kim. 'Nation Building or Cold War: Political settings for the Arnhem Land Expedition', in Exploring the Legacy of the 1948 Arnhem Land Expedition, eds Martin Thomas and Margo Neale (Canberra: ANU E Press, 2011), 55-71.

Berndt, Ronald M., and Catherine H. Berndt. Arnhem Land: Its history and its people (Melbourne: Cheshire, 1954).

Berndt, Ronald M., and Catherine H. Berndt. Man, Land and Myth in North Australia: The Gunwinggu people (Sydney: Ure Smith, 1970).

Brattain, Michelle. 'Race, Racism, and Antiracism: UNESCO and the politics of presenting science to the postwar public', American Historical Review 112:5 (2007): 1386-413.

Brothwell, Don. 'Bring out Your Dead: People, pots and politics', Antiquity 78:300 (2004): 414-18.

Davis, Michael. Writing Heritage: The depiction of Indigenous heritage in EuropeanAustralian writings (North Melbourne: Australian Scholarly Publishing and the National Museum of Australia Press, 2007).

Fitzhugh, William W. 'Foreword', in Reckoning with the Dead: The Larsen Bay repatriation and the Smithsonian Institution, eds Tamara L. Bray and Thomas W. Killion (Washington DC and London: Smithsonian Institution Press, 1994), vii-x.

Glenn, James R. 'Frank M. Setzler', in International Dictionary of Anthropologists, ed. Christopher Winters (New York: Garland Publishing, 1991), 633-4.

Harris, Amanda. 'Food, Feeding and Consumption (or the Cook, the Wife and the Nutritionist): The politics of gender and class in a 1948 Australian expedition', History and Anthropology 124:3 (2013): 363-79. 
Harris, Joshua. 'Hidden for Sixty Years: The motion pictures of the AmericanAustralian Scientific Expedition to Arnhem Land', in Exploring the Legacy of the 1948 Arnhem Land Expedition, eds Martin Thomas and Margo Neale (Canberra: ANU E Press, 2011), 239-51.

Jenkins, Mark Collins. 'A Robinson Crusoe in Arnhem Land: Howell Walker, National Geographic and the Arnhem Land Expedition of 1948', in Exploring the Legacy of the 1948 Arnhem Land Expedition, eds Martin Thomas and Margo Neale (Canberra: ANU E Press, 2011), 73-85.

Jones, Philip. 'Perceptions of Aboriginal Art: A history', in Dreamings: The art of Aboriginal Australia, ed. Peter Sutton (Ringwood: Viking, 1988), 143-79.

Jones, Philip. 'Inside Mountford's Tent: Paint, politics and paperwork', in Exploring the Legacy of the 1948 Arnhem Land Expedition, eds Martin Thomas and Margo Neale (Canberra: ANU E Press, 2011), 33-54.

Linton, Ralph, Paul S. Wingert, and Rene D'Harnoncourt. Arts of the South Seas (New York: Museum of Modern Art, 1946).

Loring, Stephen, and Miroslav Prokopec. 'A Most Peculiar Man: The life and times of Aleš Hrdlička', in Reckoning with the Dead: The Larsen Bay repatriation and the Smithsonian Institution, eds Tamara L. Bray and Thomas W. Killion (Washington and London: Smithsonian Institution Press, 1994), 26-40.

MacDonald, Helen. Human Remains: Episodes in human dissection (Carlton: Melbourne University Press, 2005).

Magaña, Linda. Mr. America's Creator: The race science of Dr. Ales Hrdlicka, 1896-1943 (Undergraduate Thesis, Columbia University, 2011).

May, Sally K. Collecting Cultures: Myth, politics, and collaboration in the 1948 Arnhem Land Expedition (Lanham: AltaMira Press, 2010).

McCarthy, Frederick D., and Frank M. Setzler. 'The Archaeology of Arnhem Land', in Records of the American-Australian Scientific Expedition to Arnhem Land: Vol. 2: Anthropology and nutrition, ed. Charles P. Mountford (Melbourne: Melbourne University Press, 1960), 215-95.

Mountford, Charles P. 'Aboriginal Decorative Art from Arnhem Land, Northern Territory of Australia', Transactions of the Royal Society of South Australia 63:2 (1939): 365-71.

Mountford, Charles P. 'Exploring Stone Age Arnhem Land', National Geographic Magazine 96:6 (1949): 745-82. 
Mountford, Charles P. Records of the American-Australian Scientific Expedition to Arnhem Land: Vol. 1: Art, myth and symbolism (Melbourne: Melbourne University Press, 1956).

Morphy, Howard. Journey to the Crocodile's Nest: An accompanying monograph to the film Madarrpa funeral at Gurka'wuy (Canberra: Australian Institute of Aboriginal Studies, 1984).

Morphy, Howard. Ancestral Connections: Art and an Aboriginal system of knowledge (Chicago: Chicago University Press, 1991).

Poole, Robert M. Explorer's House: National Geographic and the world it made (New York: Penguin, 2004).

Pullar, Gordon L. 'The Qikertarmiut and the Scientist: Fifty years of clashing world views', in Reckoning with the Dead: The Larsen Bay repatriation and the Smithsonian Institution, eds Tamara L. Bray and Thomas W. Killion (Washington DC and London: Smithsonian Institution Press, 1994), 15-25.

Smithers, Gregory D. "The Dark Side of Anti-Racism: "Half-breeds" and the anthropology of Aleš Hrdlička', Transnational Subjects: History, science and culture 1:1 (2011): 65-88.

Spencer, Baldwin. Native Tribes of the Northern Territory of Australia. London: Macmillan, 1914.

Thomas, Martin. 'A Short History of the 1948 Arnhem Land Expedition.' Aboriginal History 34 (2010): 143-69.

Thomas, Martin. 'Expedition as Time Capsule: Introducing the AmericanAustralian Scientific Expedition to Arnhem Land', in Exploring the Legacy of the 1948 Arnhem Land Expedition, eds Martin Thomas and Margo Neale (Canberra: ANU E Press, 2011), 1-30.

Thomas, Martin. 'Because It's Your Country: Death and its meanings in west Arnhem Land', Life Writing, (2013): 1-21, http://www.tandfonline.com/doi/ abs/10.1080/.VA5-4Cg4Z4g.

Thomas, Martin. 'Bones as a Bridge between Worlds: Repatriation and reconciliation between Australia and the United States', in Conciliation on Colonial Frontiers: Conflict, performance, and commemoration in Australia and the Pacific Rim, eds Kate Darian-Smith and Penelope Edmonds (New York and London: Routledge, 2015 forthcoming).

Thomas, Martin, and Margo Neale, eds, Exploring the Legacy of the 1948 Arnhem Land Expedition (Canberra: ANU E Press, 2011). 
Circulating Cultures: Exchanges of Australian Indigenous Music, Dance and Media

Turnbull, Paul. 'Indigenous Australians and Native Title', in The Dead and Their Possessions, eds Cressida Fforde, Jane Hubert and Paul Turnbull (New York: Routledge, 2004), 63-86. 
This text taken from Circulating Cultures: Exchanges of Australian Indigenous music, dance and media, edited by Amanda Harris, published 2014 by ANU Press, The Australian National University, Canberra, Australia. 